\title{
Mapping of groundwater potential zones across Ghana using remote sensing, geographic information systems, and spatial modeling
}

\author{
Murali Krishna Gumma • Paul Pavelic
}

Received: 8 November 2011 / Accepted: 24 July 2012

(C) Springer Science+Business Media B.V. 2012

\begin{abstract}
Groundwater development across much of sub-Saharan Africa is constrained by a lack of knowledge on the suitability of aquifers for borehole construction. The main objective of this study was to map groundwater potential at the country-scale for Ghana to identify locations for developing new supplies that could be used for a range of purposes. Groundwater potential zones were delineated using remote sensing and geographical information system (GIS) techniques drawing from a database that includes climate, geology, and satellite data. Subjective scores and weights were assigned to each of seven key spatial data layers and integrated to identify groundwater potential according to five categories ranging from very good to very poor derived from the total percentage score. From this analysis, areas of very good groundwater potential are estimated to cover 689,680 ha $(2.9 \%$ of the country), good potential 5,158,955 ha (21.6\%), moderate potential $10,898,140$ ha $(45.6 \%)$, and poor/ very poor potential $7,167,713$ ha $(30 \%)$. The results were independently tested against borehole yield data
\end{abstract}

\footnotetext{
M. K. Gumma

International Rice Research Institute, c/o ICRISAT,

Patancheru, Andhra Pradesh, India

e-mail: m.gumma@irri.org

M. K. Gumma

e-mail: muraligk5@gmail.com

P. Pavelic $(\bowtie)$

International Water Management Institute,

Hyderabad, Andhra Pradesh, India

e-mail: p.pavelic@cgiar.org
}

(2,650 measurements) which conformed to the anticipated trend between groundwater potential and borehole yield. The satisfactory delineation of groundwater potential zones through spatial modeling suggests that groundwater development should first focus on areas of the highest potential. This study demonstrates the importance of remote sensing and GIS techniques in mapping groundwater potential at the country-scale and suggests that similar methods could be applied across other African countries and regions.

Keywords Groundwater potential zones · GIS and remote sensing $\cdot$ Spatial modeling $\cdot$ Borehole data. Ghana

\section{Introduction}

Groundwater resources are being increasingly recognized as an invaluable but largely untapped resource for agricultural development in sub-Saharan Africa (SSA) where it offers a more food-secure alternative to rain-fed subsistence farming (FAO 2005; GIDA 2000, 2001; Masiyandima and Giordano 2007). Very little is currently known about the physical extent, accessibility, and development potential of the aquifer systems in SSA, but interest is growing and new developments are emerging across the continent (Ngigi 2009; Titus et al. 2009).

The water resources conditions for Ghana in West Africa are perhaps symptomatic of the rest of SSA. Ghana is thought to have considerable groundwater 
resources, with good but highly skewed rainfall distribution and per-capita groundwater availability many fold higher than countries such as India or China where irrigation is far more widely practiced (Giordano 2006). Opportunities for agricultural groundwater development are numerous but are hampered by lack of information at an appropriate scale.

Existing groundwater resource maps are at a very course scale and generally suitable for regional planning only, but not necessarily to support the decision making needed at a smaller scale. For example, the 1:5-M scale groundwater resources map of the world was recently updated as part of the World-wide Hydrogeological Mapping and Assessment Programme (WHYMAP 2008). A hydrogeological domain map of the entire sub-Saharan Africa region at 1:40-M scale was prepared by BGS (MacDonald and Davies 2000) which delineated the occurrence of groundwater in SSA. These global/continent scale efforts have been supplemented by various country-scale studies such as for Ethiopia, for the purposes of assessing the availability of groundwater during drought (MacDonald et al. 2001), for South Africa for groundwater balance estimation (Woodford et al. 2006), in the Volta Basin for assessing groundwater potential (Martin and van de Giesen 2005), and at the watershed scale for identifying areas irrigated by shallow groundwater (Gumma et al. 2010).

The complexity of the subsurface environment, combined with the vastness of the areas considered and associated limitations in field data acquired by ground-based surveys and exploratory drilling which are time-consuming and very expensive, supports the use of satellite-based methods. Numerous studies have shown the integration of multi-thematic maps of the earth through the application of remote sensing (RS) and geographical information system (GIS) techniques to be useful for identifying water-bearing zones for exploration and development of groundwater resources across a diverse range of hydrogeological settings (Hellden et al. 1982; Kamaraju et al. 1996; Kushwaha 1993; Mattikalli et al. 1995; Murthy 2000; Sidhu and Mehta 1989; Smith and Blackwell 1980; Trotter 1991; Rashid et al. 2011). Most of these studies have been performed in developed and developing countries where groundwater-based agriculture is already well developed.

This paper attempts to identify and rank the most prospective groundwater potential zones, in terms of the availability of groundwater, for the whole of
Ghana through RS/GIS techniques using a multithematic layer approach. In doing so, it recognizes that this is an important first step to identifying prospective locations for new groundwater development for domestic, agricultural, and industrial purposes.

\section{Study area}

Ghana is a West African country of 24 million ha that extends between $5^{\circ} 5^{\prime} 39^{\prime \prime} \mathrm{N}$ and $10^{\circ} 54^{\prime} 38^{\prime \prime} \mathrm{N}$ latitude and $0^{\circ} 05^{\prime} 04^{\prime \prime} \mathrm{E}$ and $3^{\circ} 14^{\prime} 12^{\prime \prime} \mathrm{W}$ longitude, nestled between the Gulf of Guinea to the south, Burkina Faso to the north, Togo to the east, and Ivory Coast to the west (Fig. 1). Ghana features a warm humid climate with rainfall ranging from $800 \mathrm{~mm} /$ year in the coastal zone to $2200 \mathrm{~mm} /$ year in the southwestern rainforests. In most parts of the country, there is one distinct wet season (bimodal in the south) and one dry season that tends to last longer in the northern parts of the country than in the south (Quansah 2000). Six agro-ecological zones are present but largely dominated by semideciduous forest and Guinea savannah (ISSER 2002). The topography is predominantly gently undulating with elevation mainly below $500 \mathrm{~m}$ above sea level and slopes of less than $5 \%$.

Agriculture is the backbone of the Ghanaian economy, contributing $33.6 \%$ of the GDP and employing $56 \%$ of the labor force (CIAWF 2010; ISSER 2002). Since the country is not entirely self-sufficient in food, significant problems arise when seasonal rains are poor. About $36 \%$ of Ghana's population live below a poverty line threshold of $1 \mathrm{USD} /$ day (Lamptey 2006). Rainfed farming dominates on small plots of land. Traditional farming systems have developed over time within each of the major agro-ecological zones (FAO 2005). In the forest zone, tree crops are significant with cocoa, oil palm, coffee, and rubber of particular importance. Food crop production is important across all zones. Maize is an important cereal in the south and central region, but in the north sorghum and millet dominate. Yam and grain legumes are important crops centrally and toward the north. Cultivated crops such as groundnut, beans, cowpea, cassava, and plantain are also important.

Ghana is generally well endowed with water resources; however, the amount of water available varies markedly in seasonally and inter-annually. Also the distribution of available water supplies within the 


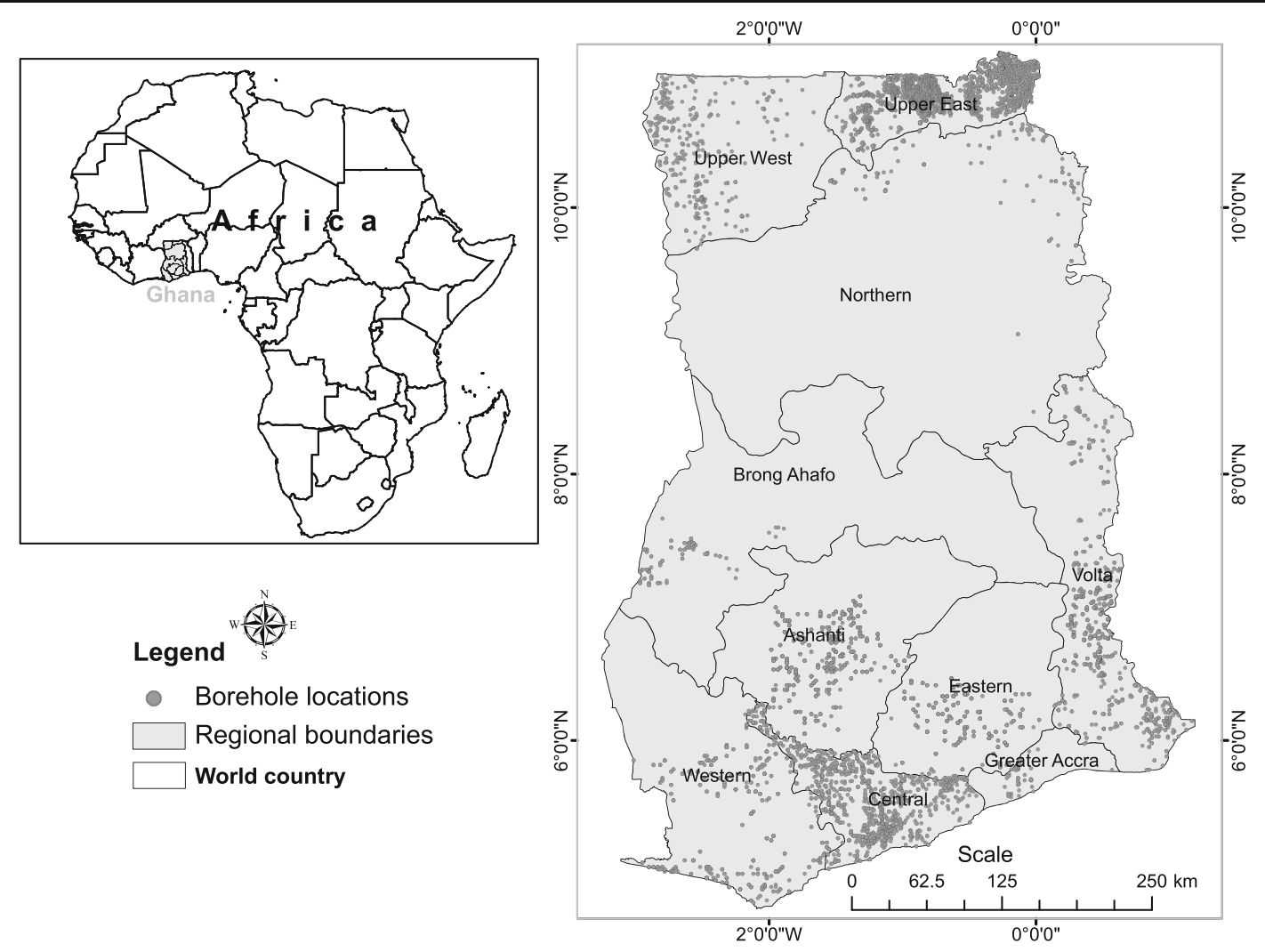

Fig. 1 Location map of Ghana indicating the ten administrative regions and observation borehole locations

country is far from uniform, with the southwestern part better endowed than the coastal and northern regions. Surface water resources revolve around several major systems, of which the Volta system is the largest, draining around $70 \%$ of the country. Vast storage capacities from the major dams and reservoirs have not translated into major irrigation development. Around 30,900 ha of land is estimated to be under water management, neglecting inland valleys and wetlands (FAO 2005). Figures from Ghana Irrigation Development Authority (GIDA) suggest that the irrigated area under full or partial control is only around 11,000 ha.

Groundwater in Ghana is associated with three major hydrogeological formations. They include the basement complex, which are comprise of crystalline igneous and metamorphic rocks; the consolidated sedimentary formations of the Volta basin, which include limestone areas; and the Mesozoic and Cenozoic sedimentary rocks (Gill 1969). The basement complex and the consolidated sedimentary formations cover 54 and $45 \%$ of the country, respectively, with the remaining $1 \%$ made up of Mesozoic/Cenozoic rocks.
Groundwater occurrence in the basement complex is associated with the development of secondary porosity as a result of jointing, shearing, fracturing and weathering. Typically, a regolith layer overlies the crystalline basement and provides potential for increased groundwater storage which can be in excess of $100 \mathrm{~m}$ thick but is typically in the range $1-70 \mathrm{~m}$ thick (Asomaning 1993). The thickness of the aquifers is normally between 10 and $60 \mathrm{~m}$, and yields rarely exceed $6 \mathrm{~m}^{3} / \mathrm{h}$ (FAO 2005). The thickness of the Mesozoic/Cenozoic aquifer varies from 6 to $120 \mathrm{~m}$. There are also limestone aquifers, which are in the order of 120 to $300 \mathrm{~m}$ thick with average yields that can be as high as $180 \mathrm{~m}^{3} / \mathrm{h}$ (CSIR/WRI 2003). The quality of groundwater is generally good for agriculture except where salinity can be problematic, particularly in some coastal aquifers.

Domestic water supplies in rural areas are almost exclusively obtained from groundwater sources, with an estimated 75,000 boreholes, dug wells, and dugouts countrywide (Obuobie and Barry in preparation). Agricultural groundwater use for irrigation of vegetables 
and livestock watering has traditionally been limited to the Volta Region, Upper East, Upper West, and Greater Accra regions.

\section{Methods of analysis}

The methodology developed here to determine groundwater potential consists of four main steps (Fig. 2). The first step starts with the identification of the thematic layers which are relevant to groundwater potential. The second involves preprocessing these thematic layers to ensure uniform projection (projection: UTM, datum: WGS84) and resolution, assigning scores, and weightages. The third step integrates all thematic layers along with scores using the spatial analysis tool in GIS software (ERDAS 2007). The final step categorizes the outputs into five classes and compares the results with borehole yield information. This study bears similarities to studies performed in other regions (Hsin et al. 2008; ICHS (Inter-African Committee for Hydraulic Studies) 1986; Kumar and Srivastava 1991; Murthy 2000; NRSA (National Remote Sensing Agency) 2000; Subba Rao 2006, 2009; Rashid et al. 2011) in terms of the approach used but is distinguishable by the larger spatial scale and finer resolution considered here.

Criteria and determining factors

The groundwater conditions at any given site can varying greatly according to various factors that
Fig. 2 Overview of the methodology for groundwater potential assessment using integrated remote sensing and GIS techniques

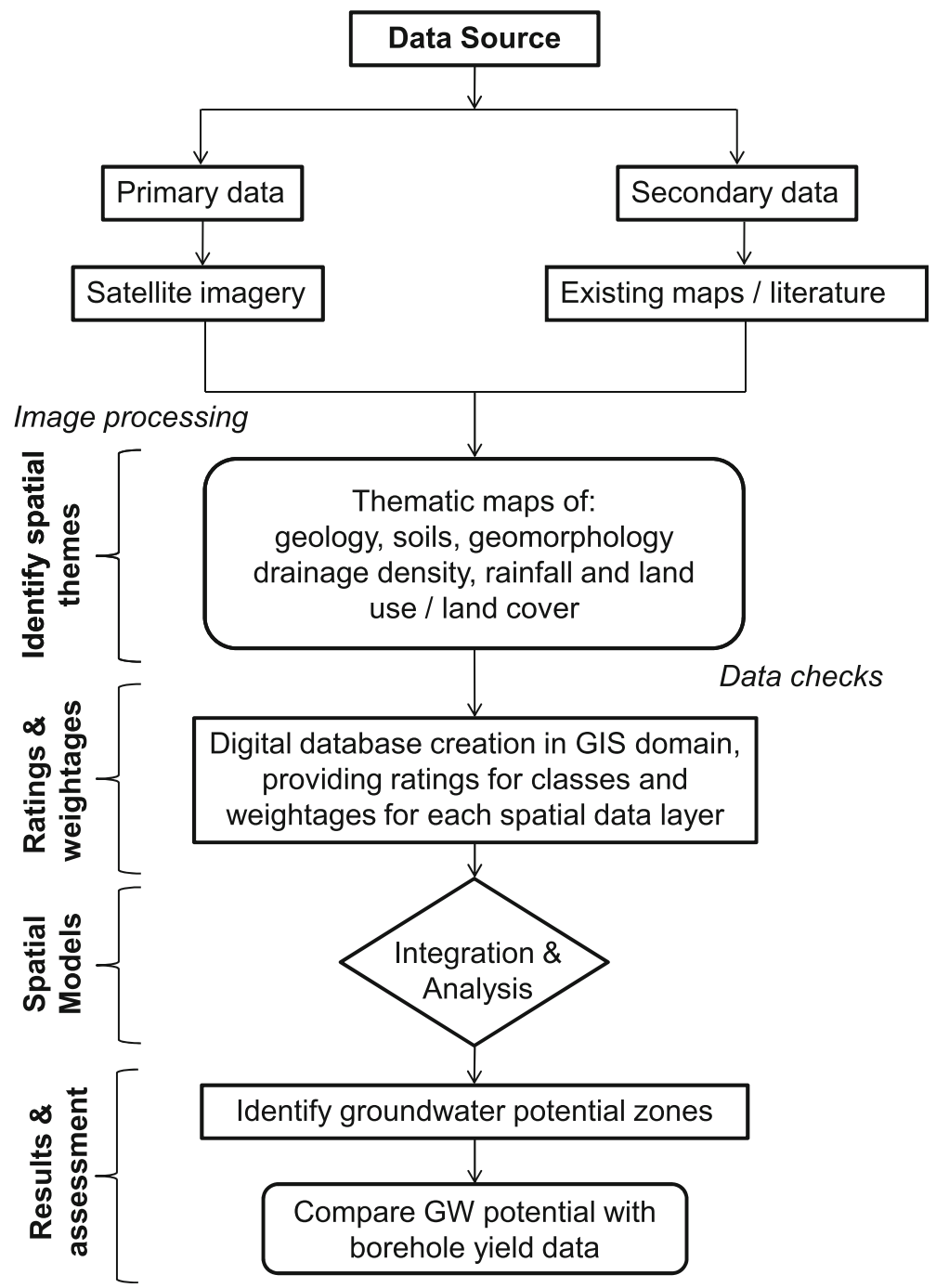


influence the occurrence and replenishment of groundwater. These factors are expressed in terms of seven thematic layers, namely geomorphology, geology, slope, drainage density, annual rainfall, land use/land cover, and soil type. Parameter estimates for each thematic layer was derived from published sources. Each layer was then divided into classes and their spatial extent identified (Table 1).
Weighted index overlay analysis (WIOA) is a simple and effective method for combining analysis of multi-class maps (Nag 2005). The strength of this method lies in the fact that human judgment/expert opinion including previous literature can be incorporated into the analysis through a weighting system. WIOA method takes into consideration the relative importance of the parameters

Table 1 Spatial distribution of the various parameters/themes, identified units within each theme and their associated areal extent within the study area

\begin{tabular}{|c|c|c|c|c|}
\hline $\begin{array}{l}\text { S } \\
\text { no. }\end{array}$ & $\begin{array}{l}\text { Parameters/ } \\
\text { theme }\end{array}$ & Identified units & Area (ha) & $\begin{array}{l}\text { Area as percentage } \\
\text { of total area }(\%)\end{array}$ \\
\hline \multirow[t]{19}{*}{1} & \multirow{19}{*}{$\begin{array}{l}\text { Geomorphology } \\
30 \mathrm{~m}\end{array}$} & Geomorphic unit & & \\
\hline & & 01. Plateau-dissected & $3,399,155$ & 14.21 \\
\hline & & 02. Uplands with valleys & $2,078,191$ & 8.69 \\
\hline & & 03.Uplands & $2,428,364$ & 10.15 \\
\hline & & 04. Plains with broad valleys & $3,296,818$ & 13.79 \\
\hline & & 05. Low lying plains & $7,112,391$ & 29.74 \\
\hline & & 06. Hills & 954,084 & 3.99 \\
\hline & & 07. Water bodies & 666,602 & 2.79 \\
\hline & & 08. Undulating slopes & 239,565 & 1.00 \\
\hline & & 09. Coastal plains & 627,763 & 2.63 \\
\hline & & 10. Deltaic plains & 94,555 & 0.40 \\
\hline & & 11. Broad valleys & 112,765 & 0.47 \\
\hline & & 12. Relict hills & 230,173 & 0.96 \\
\hline & & 13. Ridges & 64,556 & 0.27 \\
\hline & & 14. Inselberg & 17,503 & 0.07 \\
\hline & & 15. Alluvium deposit (alluvial plains/river valleys/river levees) & $2,466,614$ & 10.31 \\
\hline & & 16. Lagoons & 36,815 & 0.15 \\
\hline & & 17. Sand bars & 4,227 & 0.02 \\
\hline & & 18. Flood plains & 84,360 & 0.35 \\
\hline \multirow[t]{13}{*}{2} & \multirow{13}{*}{$\begin{array}{l}\text { Geology } \\
1: 1,000,000\end{array}$} & Geology type & $23,914,500$ & \\
\hline & & $\begin{array}{l}\text { 01. Metamorphosed lava and pyroclastic rock and hypabyssal basic intrusive, } \\
\text { phyllite, and greywacke }\end{array}$ & $1,316,682$ & 5.51 \\
\hline & & 02. Granitoid undifferentiated & $5,710,998$ & 23.88 \\
\hline & & 03. Phyllite, schist, tuff, and greywacke & $3,671,869$ & 15.35 \\
\hline & & $\begin{array}{l}\text { 04. Quartzite, phyllite, grit, conglomerate, and schist, including basic } \\
\text { intrusive }\end{array}$ & 577,166 & 2.41 \\
\hline & & 05. Mainly sandstone & $2,388,288$ & 9.99 \\
\hline & & 06. Mainly shale and mudstone beds, mainly sandy and pebbly beds & $7,978,343$ & 33.36 \\
\hline & & 07. Calcareous & 723,757 & 3.03 \\
\hline & & 08. Quartzite, sandstone, shale, phyllite, schist, and silicified limestone & 372,995 & 1.56 \\
\hline & & 09. Basaltic, andesitic, and trachytic lava, agglomerate, tuff, and jasper & 52,886 & 0.22 \\
\hline & & $\begin{array}{l}\text { 10. Acidic, ortho and paragnesis, and schist and migmatite, many of which } \\
\text { are rich in garnet, hornblende, and biotite }\end{array}$ & 445,305 & 1.86 \\
\hline & & $\begin{array}{l}\text { 11. Basic, ortho and paragnesis, and schist and migmatite, many of which are } \\
\text { rich in garnet, hornblende, and biotite }\end{array}$ & 288,658 & 1.21 \\
\hline & & 12. Red continental deposits mainly limonitic sand, sandy clay, and gravel & 87,664 & 0.37 \\
\hline
\end{tabular}


Table 1 (continued)

\begin{tabular}{|c|c|c|c|}
\hline $\begin{array}{l}\text { S Parameters/ } \\
\text { no. theme }\end{array}$ & Identified units & Area (ha) & $\begin{array}{l}\text { Area as percentage } \\
\text { of total area }(\%)\end{array}$ \\
\hline
\end{tabular}

$$
\text { no. theme }
$$

13. Marine series of shales, sandstones, limestone, glauconitic sandstone, oil 85,803

0.36 sand

14. Unconsolidated sand, clay, and gravel

$194,373 \quad 0.81$

15. Sandstone, grit, and shale

$4,572 \quad 0.02$

16. Sandstone, grit, conglomerate, shale and mudstones, nodules of

15,141

0.06

3 Slope $30 \mathrm{~m}$ limestone, and siderite

Slope distribution in $\%$

$\geq 0$ and $3 \leq$ (level to nearly level)

$5,079,208 \quad 21.24$

$\geq 3.1$ and $\leq 5$ (gentle sloping)

$5,797,833 \quad 24.24$

$\geq 5.1$ and $\leq 7$ (moderate sloping)

$4,719,154 \quad 19.73$

$\geq 7.1$ and $\leq 9$ (steep sloping)

$4,667,164 \quad 19.52$

$\geq 9.1$ (very steep sloping)

$3,651,141 \quad 15.27$

4 Drainage Watershed drainage density $\left(\mathrm{km} \mathrm{km}^{-2}\right)$ density $90 \mathrm{~m}$

$0-0.1$

$885,065 \quad 3.70$

$0.1-0.2$

$659,205 \quad 2.76$

$0.2-0.25$

$1,529,983 \quad 6.40$

$0.25-0.3$

$8,630,223 \quad 36.09$

$0.3-0.5$

$9,804,077 \quad 41.00$

Water bodies

$2,405,946 \quad 10.06$

5 Rainfall $0.5 \quad$ Annual rainfall (mm)

degree

$\geq 2,000$

542,093

2.27

$1,500-2,000$

$2,919,734 \quad 12.21$

$1,000-1,500$

$12,257,455 \quad 51.26$

$800-1,000$

$8,156,515 \quad 34.11$

$\leq 800$

$38,704 \quad 0.16$

$6 \quad$ Land use $30 \mathrm{~m}$

LU/LC category

01 . Water bodies

$765,696 \quad 3.20$

02. Settlements, open areas

$411,465 \quad 1.72$

03. Savannas: highly degraded, barren lands

$3,989,097 \quad 16.68$

04. Savannas: grasslands, scrublands, woodlands mixed with rainfed

$7,972,846 \quad 33.34$ agriculture

05. Rainfed croplands mixed savannas and some barren areas

$2,048,561 \quad 8.57$

06. Irrigated areas: medium scale, surface water dominant

$38,518 \quad 0.16$

07. Irrigated areas: minor scale and fragmented, conjunctive use

$170,159 \quad 0.71$

08. Wetland irrigation and open areas with moist soils

$543,572 \quad 2.27$

09. Lowland vegetation: typically inland valleys, scattered agriculture

$1,168,729 \quad 4.89$

10. Forests: fragmented

$5,162,858 \quad 21.59$

11. Forests: secondary re growth, younger

$532,519 \quad 2.23$

12. Forests: mature, less disturbed

$1,110,479 \quad 4.64$

7 Soils

Soil category

1:1,000,000

01. Leptosols

$2,199,553 \quad 9.20$

02. Fluvisols

$894,691 \quad 3.74$

03. Lixisols

$7,405,068 \quad 30.96$

04. Luvisols

$980,175 \quad 4.10$

05. Gleysols

215,495

0.90 
Table 1 (continued)

\begin{tabular}{|c|c|c|c|c|}
\hline $\begin{array}{l}\text { S } \\
\text { no. }\end{array}$ & $\begin{array}{l}\text { Parameters/ } \\
\text { theme }\end{array}$ & Identified units & Area (ha) & $\begin{array}{l}\text { Area as percentage } \\
\text { of total area }(\%)\end{array}$ \\
\hline & & 06. Vertisols & 851,547 & 3.56 \\
\hline & & 07. Arenosols & 175,719 & 0.73 \\
\hline & & 08. Planosols & $1,819,470$ & 7.61 \\
\hline & & 09. Plinthosols & $1,251,400$ & 5.23 \\
\hline & & 10. Acrisols & $5,690,549$ & 23.80 \\
\hline & & 11. Regosols & 3,122 & 0.01 \\
\hline & & 12. Cambisols & 238,944 & 1.00 \\
\hline & & 13. Nitosols & 135,099 & 0.56 \\
\hline & & 14. Alisols & 35,237 & 0.15 \\
\hline & & 15. Solonetz & 64,590 & 0.27 \\
\hline & & 16.Ferralsols & 472,313 & 1.98 \\
\hline & & 17. Solonchaks & 16,115 & 0.07 \\
\hline & & 18. Water body & 877,765 & 3.67 \\
\hline
\end{tabular}

and the classes belonging to each parameter by weighting. As there is no standard scale for WIOA, criteria need to be defined and each parameter assigned according to its relative importance (Gumma et al. 2009; Nag 2005; Saraf and Chowdhury 1998).

Input data and deriving analysis maps

\section{Digital elevation model (SRTM DEM)}

Space Shuttle Radar Topography Mission (SRTM) DEM data on a global scale at $90 \mathrm{~m}$ horizontal resolution is gap-filled and made available through the Consortium for Spatial Information web portal (http://srtm.csi.cgiar.org/). The SRTM DEM data were used for rapid automated delineation of the stream network and for deriving slopes by using appropriate algorithms and following sets of topographical functions, as described in ArcGIS (ESRI 2009). The process involves filling sinks, flow direction, flow accumulation, and stream network extraction and leads to generating a stream network over the entire study area. Results were then compared with topographic maps and by groundtruthing. Once the streams were accurately derived, watersheds were delineated using available subbasin-scale maps from the Geological Survey Department of Ghana.

\section{Geomorphology}

Geomorphology units are delineated from Landsat ETM+ satellite imagery along with the geology map. In the study area, 18 types of geomorphic features occur throughout Ghana (Fig. 3; Table 1). The study area includes floodplain deposits, low lying plains, valley fill deposits, sand bars, deltaic plains, structural hills, ridges, uplands, amongst others. Scores were assigned depending upon the recharge capacities of the geomorphological zones, and then weights are assigned subjectively based on thematic layer properties (Table 2). Geomorphic features such as alluvium deposits, flood plains, lineaments, deltaic plains, and sand bars that have good water-holding capacity are given the highest score of five. These areas are distributed across the entire study area, but mostly within inland valleys that contain alluvium deposits: low lying plains located in the Brong Ahato, northern, and Voltaic regions and deltaic plains located in the Accra and Voltaic regions. Hills, ridges, and hard rock areas that have poor groundwater conditions are given the lowest score of one, and these features are located in the Volta, Northern, and Ashanti regions (Fig. 3). Their respective weightages are shown in Table 2.

\section{Geology}

From the 1:1,000,000 scale geology map acquired from the Geological Survey Department of Ghana, it 
Fig. 3 Geomorphology map of Ghana (extracted from Landsat ETM+ and SRTM DEM)

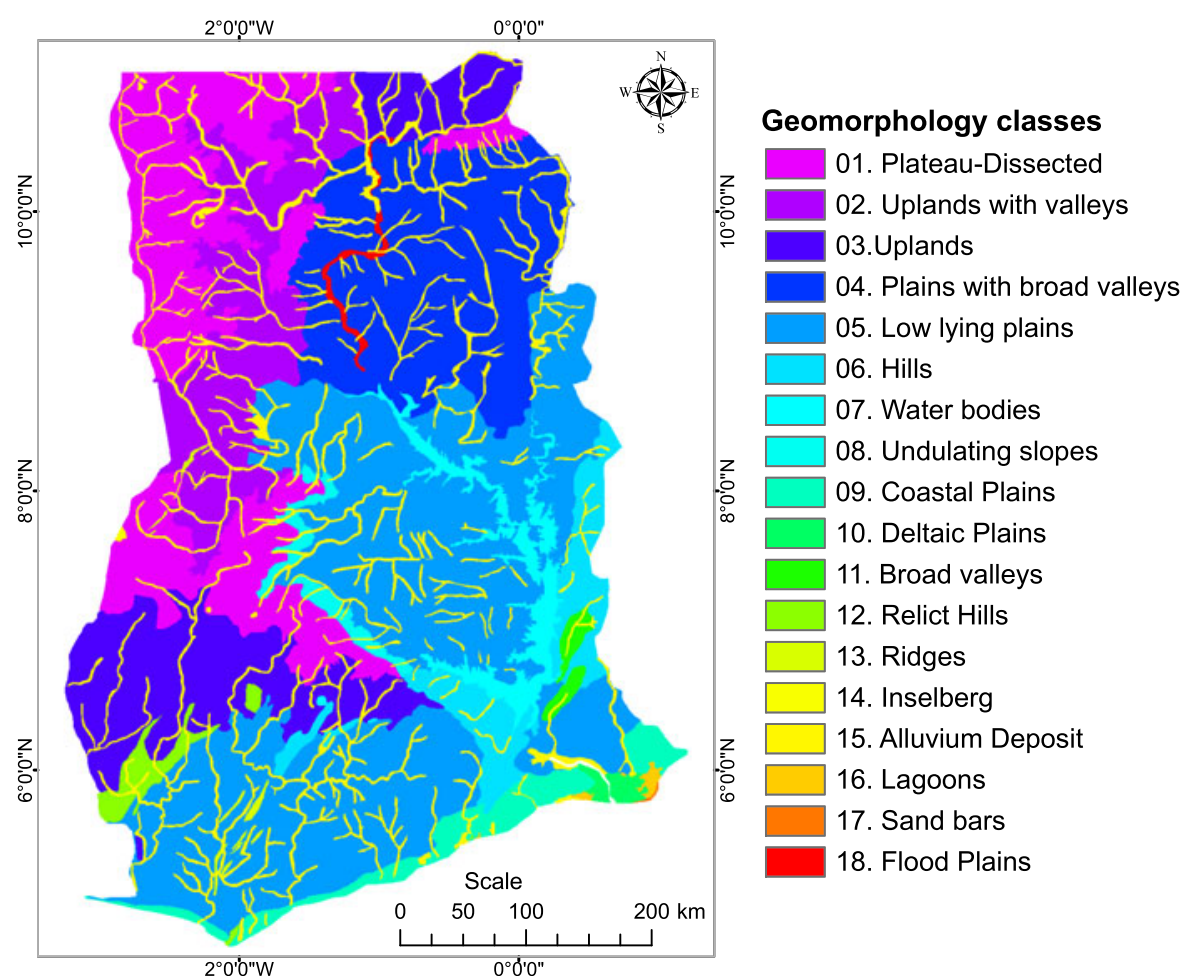

Table 2 Define scores, weightages for individual features of the seven themes for groundwater potential zones

\begin{tabular}{|c|c|c|c|c|c|}
\hline $\begin{array}{l}\text { S } \\
\text { no. }\end{array}$ & $\begin{array}{l}\text { Parameters/ } \\
\text { theme }\end{array}$ & Identified units/score & $\begin{array}{l}\text { Groundwater } \\
\text { potential score }\end{array}$ & $\begin{array}{l}\text { Score } \\
\text { assigned }\end{array}$ & Weightage \\
\hline \multirow[t]{18}{*}{1} & \multirow{18}{*}{$\begin{array}{l}\text { Geomorphology } \\
30 \mathrm{~m}\end{array}$} & 1. Plateau-dissected & Moderate & 3 & \multirow[t]{18}{*}{5} \\
\hline & & 2. Uplands with valleys & Moderate & 3 & \\
\hline & & 3.Uplands & Poor & 2 & \\
\hline & & 4. Plains with broad valleys & Moderate & 3 & \\
\hline & & 5. Low lying plains & Good & 4 & \\
\hline & & 6. Hills & Very poor & 1 & \\
\hline & & 7. Water bodies & Very good & 5 & \\
\hline & & 8. Undulating slopes & Moderate & 3 & \\
\hline & & 9. Coastal plains & Good & 4 & \\
\hline & & 10. Deltaic plains & Very good & 5 & \\
\hline & & 11. Broad valleys & Good & 4 & \\
\hline & & 12. Relict hills & Poor & 2 & \\
\hline & & 13. Ridges & Very poor & 1 & \\
\hline & & 14. Inselberg & Moderate & 3 & \\
\hline & & 15. Alluvium deposit (alluvial plains/river valleys/river levees) & Very good & 5 & \\
\hline & & 16. Lagoons & Good & 4 & \\
\hline & & 17. Sand bars & Very good & 5 & \\
\hline & & 18. Flood Plains & Very good & 5 & \\
\hline 2 & $\begin{array}{l}\text { Geology } \\
1: 1,000,000\end{array}$ & $\begin{array}{l}\text { 01. Metamorphosed lava and pyroclastic rock and hypabyssal basic } \\
\text { intrusive, phyllite, and greywacke }\end{array}$ & Very poor & 1 & 4 \\
\hline
\end{tabular}


Table 2 (continued)

S Parameters/ Identified units/score

no. theme

Groundwater

potential score

Score Weightage assigned

\begin{tabular}{|c|c|c|c|c|c|}
\hline & & 02. Granitoid undifferentiated & Good & 4 & \\
\hline & & 03. Phyllite, schist, tuff, and greywacke & Moderate & 3 & \\
\hline & & $\begin{array}{l}\text { 04. Quartzite, phyllite, grit, conglomerate, and schist, including basic } \\
\text { intrusive }\end{array}$ & Good & 4 & \\
\hline & & 05. Mainly sandstone & Moderate & 3 & \\
\hline & & 06. Mainly shale and mudstone beds, mainly sandy and pebbly beds & Moderate & 3 & \\
\hline & & 07. Calcareous & Moderate & 3 & \\
\hline & & 08. Quartzite, sandstone, shale, phyllite, schist, and silicified limestone & Moderate & 3 & \\
\hline & & 09. Basaltic, andesitic, and trachytic lava, agglomerate, tuff, and jasper & Poor & 2 & \\
\hline & & $\begin{array}{l}\text { 10. Acidic, ortho, and paragnesis and schist and migmatite, many of } \\
\text { which are rich in garnet, hornblende, and biotite }\end{array}$ & Poor & 2 & \\
\hline & & $\begin{array}{l}\text { 11. Basic, ortho, and paragnesis and schist and migmatite, many of } \\
\text { which are rich in garnet, hornblende, and biotite }\end{array}$ & Poor & 2 & \\
\hline & & $\begin{array}{l}\text { 12. Red continental deposits mainly limonitic sand, sandy clay, and } \\
\text { gravel }\end{array}$ & Good & 4 & \\
\hline & & $\begin{array}{l}\text { 13. Marine series of shales, sandstones, limestone, glauconitic } \\
\text { sandstone, oil sand }\end{array}$ & Good & 4 & \\
\hline & & 14. Unconsolidated sand, clay and gravel & Good & 4 & \\
\hline & & 15. Sandstone, grit, and shale & Moderate & 3 & \\
\hline & & $\begin{array}{l}\text { 16. Sandstone, grit, conglomerate, shale, and mudstones, nodules of } \\
\text { limestone and siderite }\end{array}$ & Moderate & 3 & \\
\hline \multirow[t]{6}{*}{3} & Slope $90 \mathrm{~m}$ & Slope distribution (\%) & & & 3.5 \\
\hline & & $\geq 0$ and $3 \leq$ (level to nearly level) & Very good & 5 & \\
\hline & & $\geq 3.1$ and $\leq 5$ (gentle sloping) & Good & 4 & \\
\hline & & $\geq 5.1$ and $\leq 7$ (moderate sloping) & Moderate & 3 & \\
\hline & & $\geq 7.1$ and $\leq 9$ (steep sloping) & Poor & 2 & \\
\hline & & $\geq 9.1$ (very steep sloping) & Very poor & 1 & \\
\hline \multirow[t]{5}{*}{4} & $\begin{array}{l}\text { Drainage } \\
\text { density } 90 \mathrm{~m}\end{array}$ & $\begin{array}{l}\text { Watershed drainage density }\left(\mathrm{km} \mathrm{km}^{-2)}\right. \\
0-0.1\end{array}$ & Very good & 5 & 4 \\
\hline & & $0.1-0.2$ & Good & 4 & \\
\hline & & $0.2-0.25$ & Moderate & 3 & \\
\hline & & $0.25-0.3$ & Poor & 2 & \\
\hline & & $0.3-0.5$ & Very poor & 1 & \\
\hline \multirow[t]{5}{*}{5} & $\begin{array}{l}\text { Rainfall } 0.5 \\
\text { degree }\end{array}$ & $\begin{array}{l}\text { Annual rainfall }(\mathrm{mm}) \\
\geq 2,000\end{array}$ & Very good & 5 & 4 \\
\hline & & $1,500-2,000$ & Good & 4 & \\
\hline & & $1,000-1,500$ & Moderate & 3 & \\
\hline & & $800-1,000$ & Poor & 2 & \\
\hline & & $\leq 800$ & Very poor & 1 & \\
\hline \multirow[t]{8}{*}{6} & Land use $30 \mathrm{~m}$ & Land use/land cover classes & & & 3.5 \\
\hline & & 01. Water bodies & Very good & 5 & \\
\hline & & 02. Settlements, open areas & Poor & 2 & \\
\hline & & 03. Savannas: highly degraded, barren lands & Poor & 2 & \\
\hline & & $\begin{array}{l}\text { 04. Savannas: grasslands, scrublands, woodlands mixed with rainfed } \\
\text { agriculture }\end{array}$ & Very good & 5 & \\
\hline & & 05. Rainfed croplands mixed savannas, and some barren areas & Moderate & 3 & \\
\hline & & 06. Irrigated areas: medium scale, surface water dominant & Very good & 5 & \\
\hline & & 07. Irrigated areas: minor scale and fragmented, conjunctive use & Very good & 5 & \\
\hline
\end{tabular}


Table 2 (continued)

\begin{tabular}{|c|c|c|c|c|c|}
\hline $\begin{array}{l}\mathrm{S} \\
\text { no. }\end{array}$ & $\begin{array}{l}\text { Parameters/ } \\
\text { theme }\end{array}$ & Identified units/score & $\begin{array}{l}\text { Groundwater } \\
\text { potential score }\end{array}$ & $\begin{array}{l}\text { Score } \\
\text { assigned }\end{array}$ & Weightage \\
\hline \multirow{24}{*}{7} & \multirow{24}{*}{$\begin{array}{l}\text { Soils } \\
\qquad 1: 1,000,000\end{array}$} & 08. Wetland irrigation and open areas with moist soils & Very good & 5 & \multirow{24}{*}{3.5} \\
\hline & & 09. Lowland vegetation: typically inland valleys, scattered agriculture & Good & 4 & \\
\hline & & 10. Forests: fragmented & Moderate & 3 & \\
\hline & & 11. Forests: secondary regrowth, younger & Poor & 2 & \\
\hline & & 12. Forests: mature, less disturbed & Very poor & 1 & \\
\hline & & Soil type & & & \\
\hline & & 01. Leptosols & Very poor & 1 & \\
\hline & & 02. Fluvisols & Very good & 5 & \\
\hline & & 03. Lixisols & Good & 4 & \\
\hline & & 04. Luvisols & Moderate & 3 & \\
\hline & & 05. Gleysols & Moderate & 3 & \\
\hline & & 06. Vertisols & Moderate & 3 & \\
\hline & & 07. Arenosols & Moderate & 3 & \\
\hline & & 08. Planosols & Good & 4 & \\
\hline & & 09. Plinthosols & Moderate & 3 & \\
\hline & & 10. Acrisols & Poor & 2 & \\
\hline & & 11. Regosols & Very good & 5 & \\
\hline & & 12. Cambisols & Good & 4 & \\
\hline & & 13. Nitosols & Good & 4 & \\
\hline & & 14. Alisols & Good & 4 & \\
\hline & & 15. Solonetz & Good & 4 & \\
\hline & & 16.Ferralsols & Moderate & 3 & \\
\hline & & 17. Solonchaks & Poor & 2 & \\
\hline & & 18. Waterbody & Very good & 5 & \\
\hline
\end{tabular}

is noted that across the study area, there are 16 types of geologic formations (Fig. 4; Table 1). About two thirds of Ghana is dominated by Birimian rocks consisting of five evenly spaced volcanic belts trending northeast to southwest. Limonitic sand, clay, gravels (Tertiary), sandstone, limestone (Cretaceous), and unconsolidated sand/clay/gravel (Recent era) are considered to have the greatest water bearing potential, and hence, higher scores have been given. These are located in the upper eastern, upper western, Brong Ahafo, and Ashanti regions. Buem volcanic, Dahomeyan, Togo series, and older alluvium deposits are considered to be less favorable for groundwater development compared to younger alluvium and so lower scores have been given. These areas are located in Upper West, Volta, and greater Accra regions. The weightages for each geological type are given in Table 2.
Slope

The SRTM DEM data were used to derive a slope map presented in percentage terms using the SLOPE function in ArcGIS. The gradient of slope is one of the factors that directly influence the infiltration of rainfall in that steeper slopes generate less recharge because water runs rapidly off the surface during rainfall, allowing insufficient time to infiltrate the surface and recharge the saturated zone. Slope is classified into five categories along with their areal extent (Fig. 5; Table 1) and weightages shown in Table 2. Weights were assigned according to the slope aspect. A score of five is given to the plain region with lower slope because low runoff is usually a good recharge zone. These areas are mainly located in the Volta basin (northern, upper east, and upper west regions) and steep hills (slope $>10 \%$, higher slope) which are given 
Fig. 4 Geology map of Ghana (taken from Geological Survey Department of Ghana, Ghana: http:// www.ghana-mining.org)

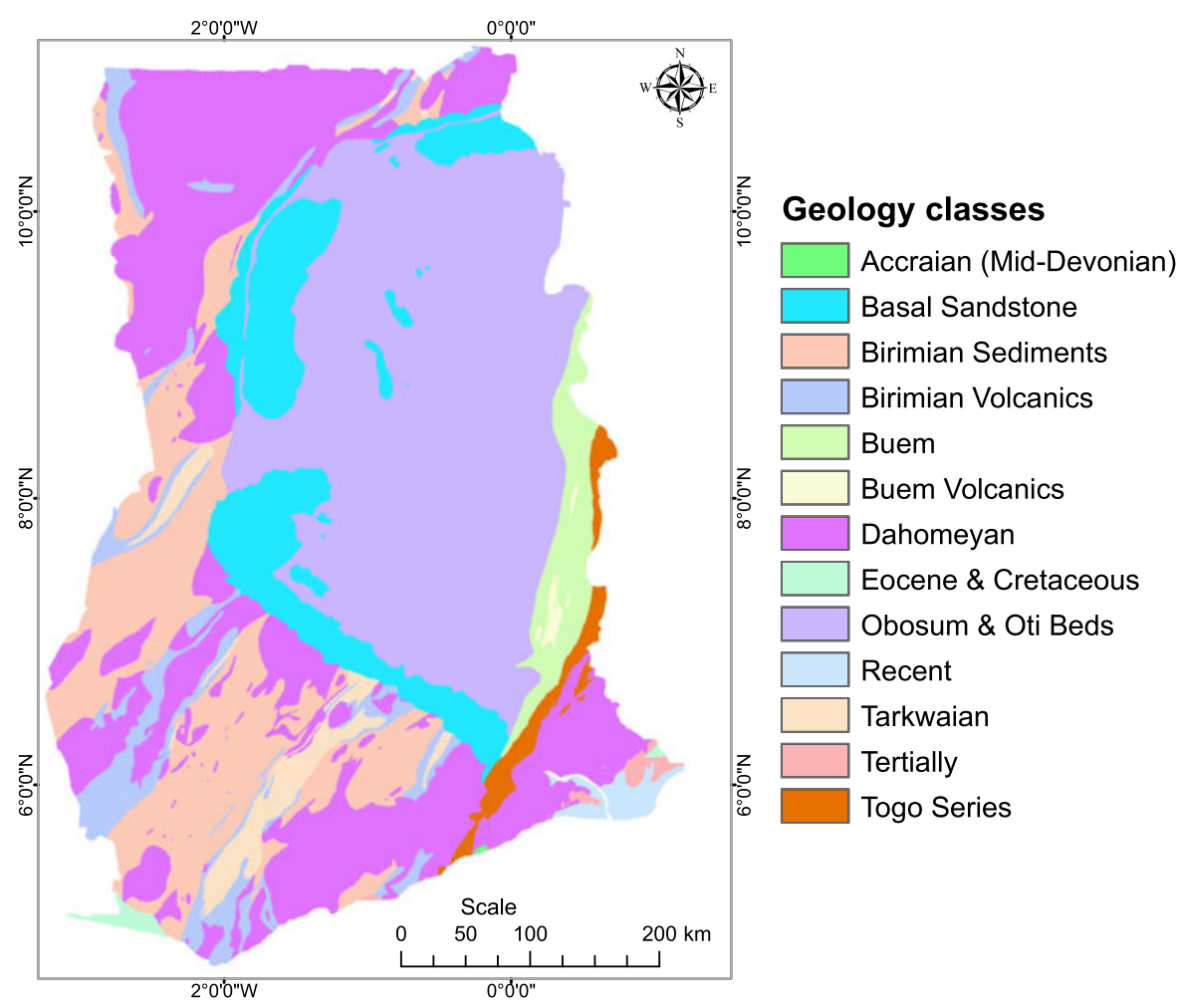

Volta region, and Eastern parts of the study area (hilly areas).
Fig. 5 Slope map of Ghana (extracted from SRTM DEM: http://srtm.csi.cgiar.org/

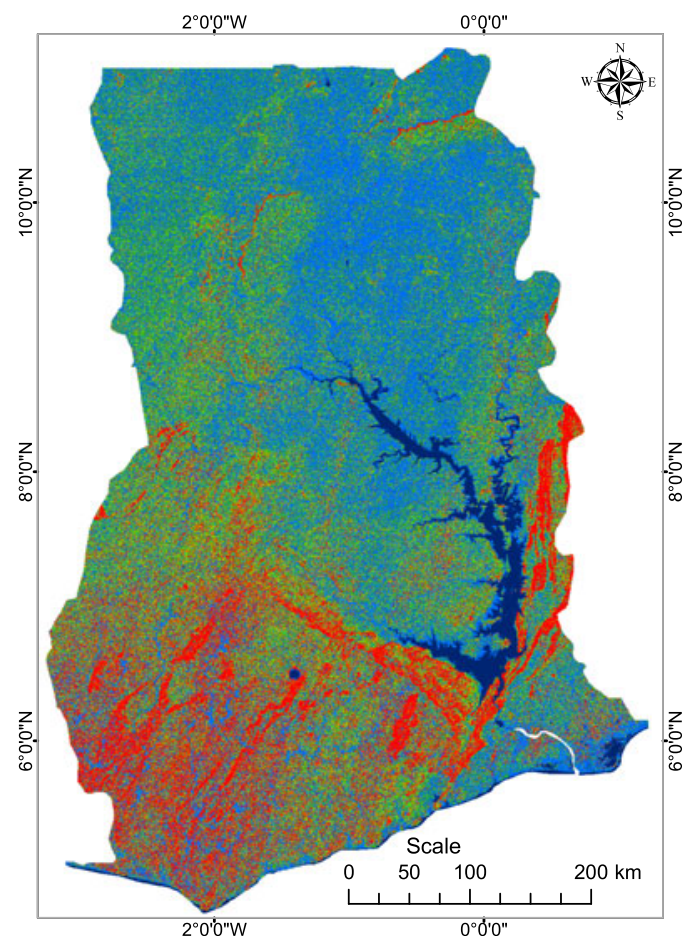

\section{Slope classes}

Slope $\%$ range

$\geq 0 \& 3 \leq$ (level to nearly level)

$\geq 3.1 \& \leq 5$ (Gentle sloping)

$\geq 5.1 \& \leq 7$ (Moderate sloping)

$\geq 7.1 \& \leq 9$ (Steep sloping)

$\geq 9.1$ (Very steep sloping)

Water bodies 


\section{Drainage density}

The density of the drainage network as well as the occurrence of lineaments, such as faults, fracture, major or minor joints, can have a major influence on groundwater recharge and movement (Murthy 2000; Kumar et al. 2007) also provides pathways for groundwater movement and is hydrologically very important. Generally, areas close to lineaments in hard rock areas offer good opportunities for groundwater development (Murthy and Mamo 2009). Since the largest proportion of rainwater goes to runoff, a higher drainage density tends to indicate lower groundwater potential. A drainage density map was prepared which served as one of the primary data sets. The five infiltration categories were given weights starting from five (i.e., very good) corresponding to a low drainage density values found in greater Accra region, along coastal areas and major inland valleys to a value of one (poor) for high drainage density, or poor infiltration zones, as located in Ashanti, eastern, and voltaic regions (upland hilly areas). Medium drainage densities are located in western part of the study areas (Fig. 6; Table 1) and weightages shown in Table 2.

The drainage density map was created in three stages. In the first stage, the drainage map was prepared from the SRTM DEM; next the watersheds were delineated based on Geological Survey Department of Ghana reference maps using SRTM DEM; and finally, drainage densities were calculated in each of the grid square using Eq. 1 as given below from (Murthy 2000):

$\mathrm{DD}=\Sigma L_{\mathrm{ws}} / A_{\mathrm{ws}}$

where

DD drainage density

$L_{\mathrm{ws}}$ total length of streams in watershed

$A_{\text {ws }} \quad$ area of the watershed

\section{Rainfall}

Mean annual rainfall data for a 10-year period (19952005) was adopted from Ghana Meteorological Services Department, Accra, Ghana. Rainfall is known to be the dominant source of groundwater recharge across all climatic regions (Obuobie and Barry in preparation). Rainfall data were classified into five categories and its spatial extent as shown by Fig. 7 . Ghana was divided into five categories of rainfall zones ranging from $<800$ to $>2,000 \mathrm{~mm}$ along with their areas shown (Table 1) and weightages shown (Table 2). The area receiving less than $800 \mathrm{~mm}$ of rainfall was given a score of one assuming a poor potential zone, which are mainly located in greater Accra region, Ashanti, Upper East, and Upper West regions while an area receiving greater than $2,000 \mathrm{~mm}$ of rainfall was assigned a score of five assuming very good water potentiality. These areas are located in western, central, and eastern parts of the Ghana (Fig. 7).

\section{Land use/land cover}

Land use/land cover patterns and areas (Fig. 8; Table 1) were analyzed and mapped using Landsat ETM+ $30 \mathrm{~m}$ satellite imagery (Gumma et al. 2011; Thenkabail et al. 2004a). Irrigated land was assigned a score of five because it is mostly associated with flood plains and buried channels, which are very good recharge zones, as indicated by ground-truthing in the Upper East region by Gumma et al. (2011). One of the dominant land use/land cover categories in the area is class 4 : savannas: grasslands, shrub lands, and woodlands mixed with rainfed agriculture. Due to the high degree of slope and thin soil cover, the groundwater prospects are considered to be poor, and a score of one is assigned. Similarly, weights have been assigned subjectively to each of the categories of the land use/land cover patterns according to their influence on infiltration and runoff. The land use/land cover such as high gradient hill areas and settlements which have poor water-holding capacity have been given a score of one while savanna grass lands, irrigated areas, and wetlands which are high water-holding capacity have been given a score of five (Table 2).

Soils

Eighteen soil units such as Leptosols, Luvisols, Lixisols, etc. are distributed across the study area (Fig. 9; Table 1). Weights are assigned subjectively to each soil unit after taking into account the type of soil and its water-holding capacity. Groundwater recharge 
Fig. 6 Drainage density map of Ghana (extracted from SRTM drainage network and Geological Survey Department of Ghana approximate sub-basins)
Fig. 7 Rainfall map of Ghana (taken from IWMIDSP,

www.iwmidsp.org)
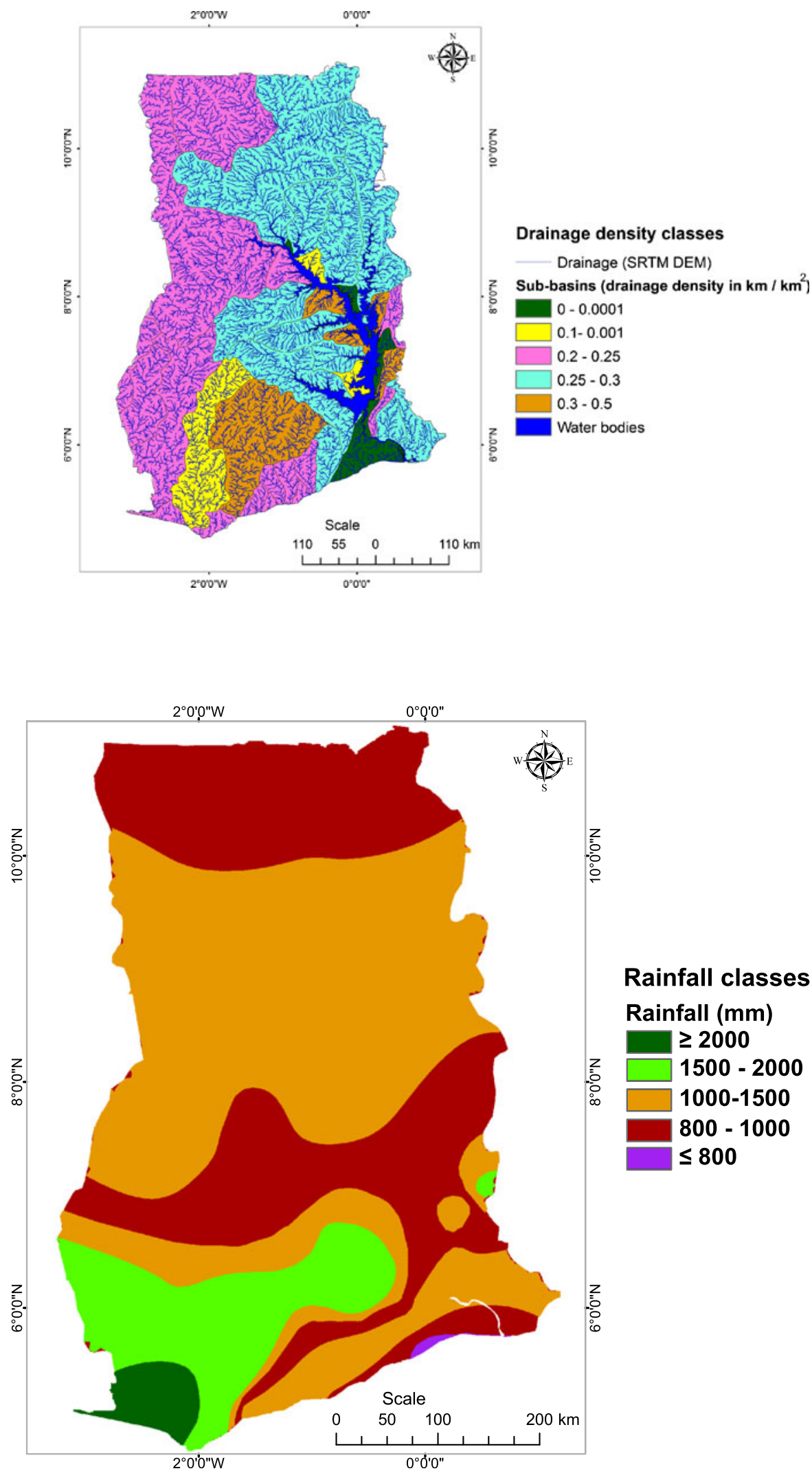


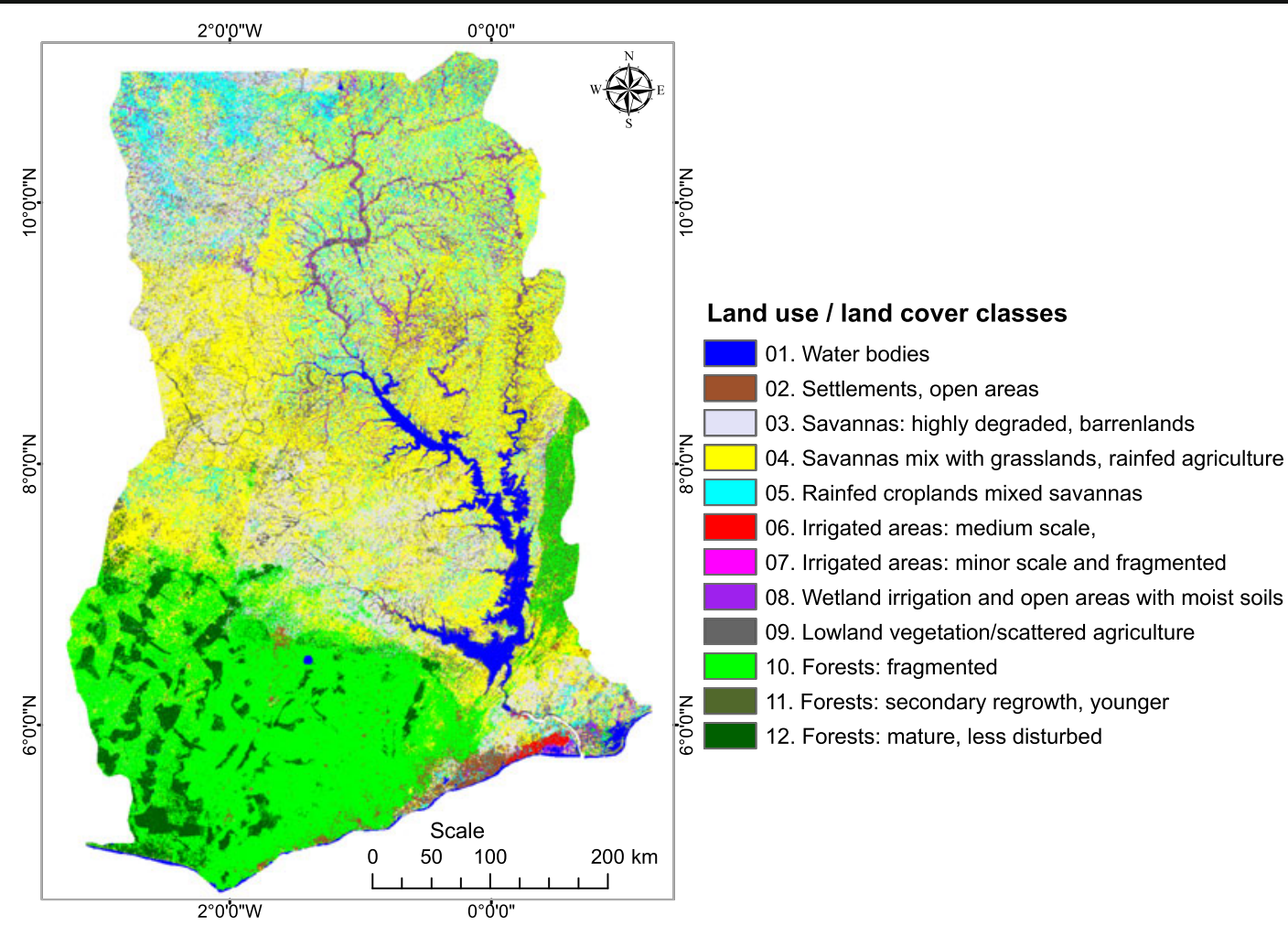

Fig. 8 Land use/land cover classes in the Ghana, during year of 2000-2001 (extracted from Landsat ETM+ and MODIS 500-m time series data)

capacity is less on hills due to the steep slopes (more than $5 \%$ gradient), and hence, the runoff is more. Soils, such as Leptosols and Solonchaks, have poor water-holding capacity and have been given a score of 1. Such areas are located in the Volta, Upper West, Western, and Ashanti regions. Planosols, Regosols, etc. have high water-holding capacity and have been given a score of 5 (Table 2). These areas are located in Upper East, Northern parts, and small portion of the Accra region.

\section{Determining theme weightages}

Suitable weights were assigned to the seven theme layers and their individual features, taking account of their likely importance for groundwater occurrence and replenishment. The weights were assigned based on thematic layer properties and from the literature (Murthy 2000; Murthy and Mamo 2009) and are presented in Table 2. The main idea behind assigning scores and weights to each of the thematic layers is that they play a major role in groundwater potential including infiltration, aquifer transmission, and storage. The importance of each individual theme relative to the sum total is as follows: geomorphology $18.18 \%$, geology $14.55 \%$, slope $12.73 \%$, drainage density $14.55 \%$, rainfall $14.55 \%$, land use/land cover 12.73 , and soils $12.73 \%$. Clearly, the higher the weight, the more influence a particular factor will have in the groundwater potential. Almost all thematic layers have similar important in influencing groundwater potential, with geomorphology more important to some extent. It is assumed that geomorphology has the greatest role in this analysis, and its assigned weightage is given a score of five, while drainage density, geology, and rainfall have the next most important weightage of four followed by slope, soils, and land use/land cover that were assigned a weightage of three and a half. These weightages were assigned based on expert knowledge and previous literature where good results had been achieved. In this study, we defined the maximum weightage as five and the minimum weightage as one. 
Fig. 9 Soil map of Ghana (taken from Geological Survey Department of Ghana, Ghana: http://www.ghanamining.org)

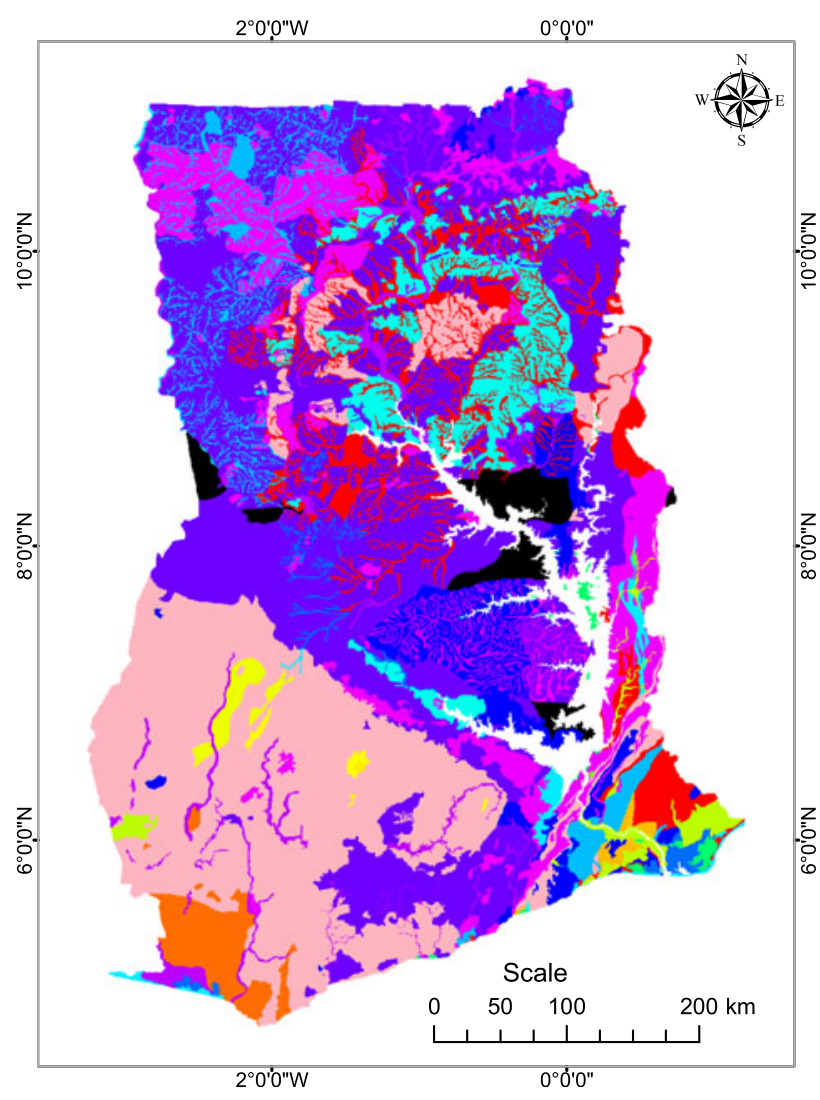

Integration of thematic layers and spatial model

The first step in the spatial model development is to have a clear knowledge of how the spatial data layers and the classes within each spatial data theme are scored (Table 2). Once this is achieved, the next step is to build the spatial model. This was done with the ERDAS software using the spatial modeler module. Integration of all reclassified themes made use of the weighted overlay analysis, as given below in Eq. 2:

$\mathrm{GPS}_{\mathrm{P}}=\Sigma T_{\mathrm{GW}} \times F_{\mathrm{W}}$

where

GPS $_{\mathrm{P}}$ groundwater potential score of each pixel

$T_{\mathrm{GW}} \quad$ selected groundwater potential theme

$F_{\mathrm{W}} \quad$ weightage factor of theme

The maximum score for geomorphology was 25 , geology 16 , slope 17.5 , drainage density 20 , rainfall 20 , land use/land cover 17.5, and soils 17.7 (Table 3), with a maximum resultant score of 133.5 .

\section{Results and discussion}

Groundwater potential zoning

On the basis of the $\mathrm{GPS}_{\mathrm{P}}$ value, groundwater potential zones were classified into five classes: (a) very good, (b) good, (c) moderate, (d) poor, and (e) very poor across the study area (Fig. 10; Table 4). It indicates that areas with moderate to very good groundwater potential are widely distributed across most parts of the country. The total area underlain by very good groundwater potential is 689,680 ha or $2.9 \%$ of the total geographical area, good groundwater potential is $5,158,996$ ha $(21.6 \%)$, moderate potential is $10,898,140$ ha $(45.6 \%)$, poor potential is $6,487,492$ ha $(27.1 \%)$, and very poor potential is 680,222 ha $(2.8 \%)$.

Good groundwater potential areas are situated in areas comprised of Quaternary alluvium deposits and sand beds, flood plains, deltaic plains, and coastal plains, also these area laying in low drainage density areas. Moderate potential areas fall in 
Table 3 Approach used to determine weights and maximum scores of the seven themes

\begin{tabular}{llllll}
\hline Theme & Theme weight & Score range & Maximum possible score & Scores given & Maximum possible total pixel score \\
\hline 1. Geomorphology & 5 & $1-5$ & 5 & $5,4,3,2,1$ & $5 \times 5=25$ \\
2. Geology & 4 & $1-5$ & 5 & $5,4,3,2,1$ & $4 \times 5=20$ \\
3. Slope & 3.5 & $1-5$ & 5 & $5,4,3,2,1$ & $3.5 \times 5=17.5$ \\
4. Drainage density & 4 & $1-5$ & 5 & $5,4,3,2,1$ & $4 \times 5=20$ \\
5. Rainfall & 4 & $1-5$ & 5 & $5,4,3,2,1$ & $4 \times 5=20$ \\
6. LULC & 3.5 & $1-5$ & 5 & $5,4,3,2,1$ & $3.5 \times 5=17.5$ \\
7. Soils & 3.5 & $1-5$ & 5 & $5,4,3,2,1$ & $3.5 \times 5=17.5$ \\
\hline
\end{tabular}

Inselberg, sediments, and undivided Quaternary alluvium. The Quaternary alluvium deposits and all the metamorphic basements (maficultramafic-volcano-sedimentary assemblages, gneissic and migmatitic complexes, Precambrian-early Paleozoic basement complexes) are collectively categorized as poor groundwater potential zones. Relict hills and ridges have the poorest groundwater potential.

This analysis suggests that 5.8 Mha of Ghana has a good or better groundwater potential and could be suitable for agricultural groundwater development. This figure is three-fold higher than the total area of surface water and groundwater irrigated identified by Asomaning (1993) and more than two-fold higher than the total cultivatable area of the country determine by Gumma et al. (2011). There would appear to be opportunities for useful expansion of groundwaterbased irrigation across some parts of the country identified through this study.

\section{Comparisons with borehole data}

Borehole yield data were obtained from the CSIRWater Research Institute who had compiled the
Fig. 10 Groundwater potential zones map of Ghana

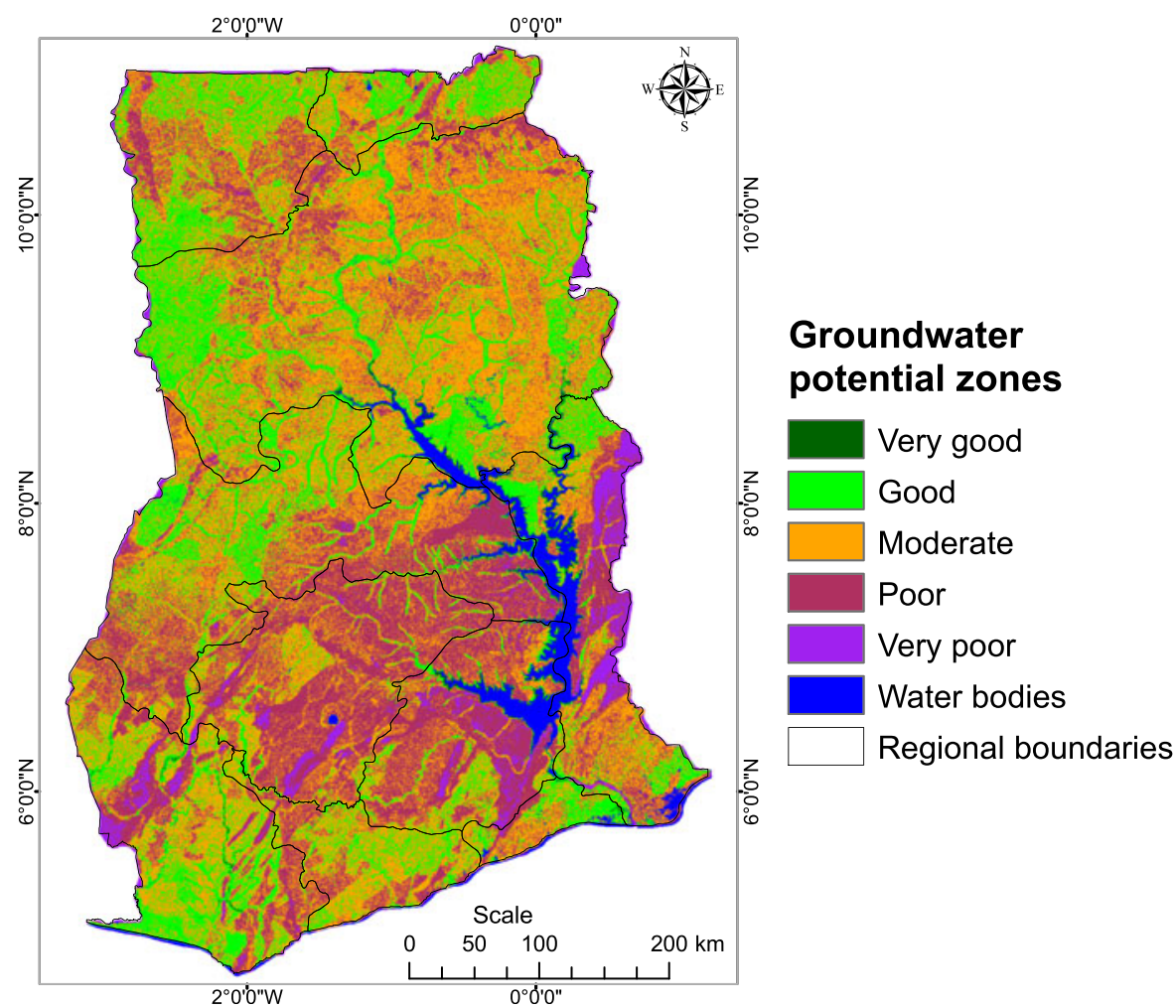


Table 4 Groundwater potential zones classification across the study area and their percentage extent

\begin{tabular}{lllc}
\hline $\begin{array}{l}\text { Groundwater potential } \\
\text { class }\end{array}$ & $\begin{array}{l}\text { Total score } \\
(\%)\end{array}$ & Area (ha) & $\begin{array}{l}\text { \% in total } \\
\text { area }\end{array}$ \\
\hline Very good & $100-85$ & 689,680 & 2.9 \\
Good & $85-70$ & $5,158,966$ & 21.6 \\
Moderate & $70-60$ & $10,898,140$ & 45.6 \\
Poor & $60-45$ & $6,487,492$ & 27.1 \\
Very poor & $\leq 45$ & 680,222 & 2.8 \\
\hline
\end{tabular}

data from various sources. In total, 2,650 wells were used which are almost entirely distributed in five of the ten administrative regions (Central, Greater Accra, Volta, Upper East, and Upper West), as indicated in Fig. 1. Yields were determined by airlift methods in all cases and therefore represent an upper limit which would generally be higher than the long-term pumping rate. The borehole yields in each of the groundwater potential score zones were aggregated, and the average value is plotted (Fig. 11). The positive correlation confirms that the highest groundwater potential coincides with areas of higher borehole yields.

\section{Conclusions}

This research illustrates the application of remote sensing and geographic information systems based modeling for determining the suitability of the aquifer systems across Ghana to support groundwater development for agricultural and domestic purposes. The process involved (a) identifying and developing harmonized spatial data layers of importance, (b) providing weightages to themes and classes within each data theme based on thematic unit properties, (c) developing spatial models, and (d) running spatial models using spatial data and their weightages to arrive at groundwater potential zones. This leads to the determination of five classes of groundwater potential. Of the total country area, $2.9 \%(689,680$ ha $)$ has very good potential and $21.6 \%(5,158,955$ ha $)$ has good potential for groundwater development. The reliability of the model was assessed against 2,650 measured borehole yields.

This showed that $24.5 \%$ of the total geographic area has very good to good groundwater potential, and it is in these areas where groundwater development should first be focused. Less than $1 \%$ of total geographical area is estimated to be currently irrigated (FAO 2005; GIDA 2001; Thenkabail et al. 2000), showing that if groundwater is developed properly, there is huge potential for increasing the area under irrigation that would not only contribute to addressing food security but also offer potential for food exports. Alluvial deposits (inland valleys) in particular, which constitute $11 \%$ of the total area of the country and are only cultivated to a limited degree (Gumma et al. 2009), have notably high development potential.

These results suggest that the high potential zones will have a key role in future expansion of
Fig. 11 Mean borehole yields in relation to the groundwater potential zone classifications

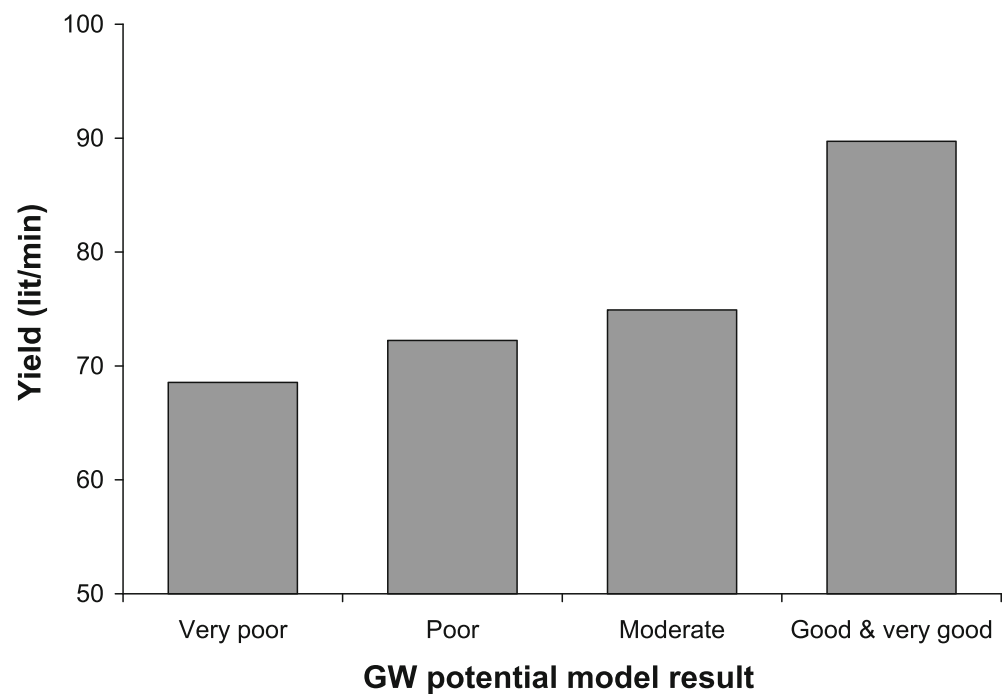


irrigation development in Ghana. The types of data used for this study are likely to be widely available and so the techniques applied are likely to be applicable to other African countries and regions. The mapping approach used here can help to prioritize areas and provide support for site-specific field investigations.

Acknowledgments This study was financially supported by the Rockefeller Foundation through project number 2008-AGR305 "Groundwater in sub-Saharan Africa: Implications for food security and livelihoods" as a part of the CGIAR Research Program on Climate Change, Agriculture and Food Security. The authors would like to sincerely thank Dr. Mehnaz for generating the geomorphology map and Dr. Emmanuel Obuobie (CSIR-Water Research Institute) and Mr. Gerald Forkuor (IWMI) for data provision and peer review of this work. We are grateful to the Geological Survey Department of Ghana for access to the soils, geology, and watershed boundary data that enabled this research to proceed. The lead author would like to also thank Dr. Andrew Nelson and Dr. Alice Laborte (IRRI) for their encouragement during the latter stages of the research.

\section{References}

Asomaning, G. (1993). Groundwater resources of the Birim basin in Ghana. Journal of African Earth Sciences (and the Middle East), 15(3-4), 375-384. no. 3-4.

CIAWF. (2010). Ghana Economy 2010 (http://www.theodora. com/wfbcurrent/ghana/ghana_economy.html).

CSIR/WRI. (2003). Groundwater assessment: an element of integrated water resources management-the case of Densu River Basin, July 2003. http://www.wrc-gh.org/ nationalwaterpolicy.html.

ERDAS. (2007). ERDAS field guide, Volume 1, October 2007. ESRI. (2009). ESRI Field Guide, Volume 1, October 2009.

FAO. (2005). Aquastat, FAO water report 29, 2005. http:// www.fao.org/nr/water/aquastat/countries/ghana/index.stm.

GIDA. (2000). Annual report. Ghana: Ghana Irrigation Development Authority.

GIDA. (2001). General information on public irrigation projects in Ghana. Ghana: Ghana Irrigation Development Authority.

Gill, H. E. (1969). A ground-water reconnaissance of the Republic of Ghana, with a description of geohydrologic provinces. US Geological Survey water-supply paper 1757-K (pp. 1-37). Washington, DC: US Geological Survey.

Giordano, M. (2006). Agricultural groundwater use and rural livelihoods in sub-Saharan Africa: a first-cut assessment. Hydrogeology Journal, 14(3), 310-318. no. 3.

Gumma, M. K., Thenkabail, P. S., Fujii, H., \& Namara, R. (2009). Spatial models for selecting the most suitable areas of rice cultivation in the Inland Valley Wetlands of Ghana using remote sensing and geographic information systems. Journal of Applied Remote Sensing, 3, 033537.

Gumma, M. K., Thenkabail, P. S., \& Barry, B. (2010). Delineating shallow groundwater irrigated areas in the
Atankwidi watershed (northern Ghana, Burkina Faso) using Quickbird 0.61-2.44 meter data. African Journal of Environmental Science and Technology, 4(7), 455-664. no. 7 .

Gumma, M. K., Thenkabail, P. S., Hideto, F., Nelson, A., Dheeravath, V., \& Busia, D. (2011). Mapping irrigated areas of Ghana using fusion of $30 \mathrm{~m}$ and $250 \mathrm{~m}$ resolution remote-sensing data. Remote Sensing, 3(4), 816-835.

Hellden, U., Olsson, L., \& Stern, M. (1982). Approaches to desertification monitoring in Sudan. In L. G. Lery (Ed.), Satellite remote sensing in developing counties (pp. 131144). Paris: European Space Agency.

Hsin, F. Y., Cheng, H. L., Kuo, C. H., \& Change, P. H. (2008). GIS for assessment of the groundwater recharge potential. Environmental Geology, 58, 185-195.

ICHS (Inter-African Committee for Hydraulic Studies). (1986). Explanatory notice and recommended usage of the map of potential groundwater resources in western and central Africa 1:5,000,000. Orléans: ICHS, BRGM.

ISSER. (2002). The state of the Ghanaian economy. Ghana: The Institute of Statistical, Social and Economic Research (ISSER), University of Ghana.

Kamaraju, M. V. V., Bhattacharya, A., Sreenivasa, R., Chandrasekhar, R., Murthy, G. S., \& Malleswara Rao, T. C. H. (1996). Ground-water potential evaluation of West Godavari district, Andhra Pradesh State, India-a GIS approach. Ground Water, 34, 318-325.

Kumar, A., \& Srivastava, S. K. (1991). Geomorphological unit, their geohydrological characteristics and vertical electrical sounding response near Mungre, Bhihar. J. Indian Society of Remote Sensing, 19(4), 205-215.

Kumar, P. K. D., Gopinath, G., \& Seralathan, P. (2007). Application of remote sensing and GIS for the demarcation of groundwater potential zones of a river basin in Kerala, southwest coast of India. International Journal of Remote Sensing, 28(24), 5583-5601.

Kushwaha, S. P. S. (1993). Application of remote sensing in shifting cultivation areas. Technical report (pp. 23-28). Freiburg: Abteilung Luftbildmessung and Fernerkundung, Universitat Freiburg.

Lamptey, N.L. (2006). Urban poverty reduction project launched. Daily Graphic, 4-3-06, p. 18

MacDonald, A.M. and Davies, J. (2000). A brief review of groundwater for rural water supply in sub-Saharan Africa. British Geological Survey technical report WC/00/33.

MacDonald, A.M., R.C. Calow, A.L. Nicol, B. Hope, and N.S. Robins. (2001). Ethiopia: water security and drought. British Geological Survey technical report WC/01/02.

Martin, N., \& van de Giesen, N. (2005). Spatial distribution of groundwater production and development potential in the Volta river basin of Ghana and Burkina Faso. Water International, 30(2), 239-249.

Masiyandima, M., \& Giordano, M. (2007). Sub-Saharan Africa: opportunistic exploitation. In M. Giordano \& K. Villholth (Eds.), The agricultural groundwater revolution: opportunities and threats to development (pp. 79-99). Wallingford: CABI.

Mattikalli, H. M., Devereux, B. J., \& Richards, K. S. (1995). Integration of remote sensed satellite images with a geographical information system. Computers and Geosciences, 21, 947-956. 
Murthy, K. S. R. (2000). Groundwater potential in a semi-arid region of Andhra Pradesh - a geographical information system approach. International Journal of Remote Sensing, 21(9), 1867-1884.

Murthy, K. S. R., \& Mamo, A. G. (2009). Multi-criteria decision evaluation in groundwater zones identification in MoyaleTeltele subbasin, South Ethiopia. International Journal of Remote Sensing, 30(11), 2729-2740.

Nag, S. K. (2005). Application of lineament density and hydrogeomorphology to delineate groundwater potential zones of Baghmundi block in Purulia district, West Bengal. Journal of Indian Society of Remote Sensing, 33(4), 521-529.

Ngigi, S. N. (2009). Climate change adaptation strategies: water resources management options for smallholder farming systems in sub-Saharan Africa. New York: The MDG Centre for East and Southern Africa, The Earth Institute at Columbia University. 189p.

NRSA (National Remote Sensing Agency). (2000). Methodology manual of ground water prospective zone maps. Rajiv Gandhi National Rural Drinking Water Mission, technical guidelines for preparation of ground water prospects maps (pp. 17-18). Hyderabad: Department of Space.

Quansah, C. (2000). Country case study: Ghana. In FAO: integrated soil management for sustainable agriculture and food security FAO-RAF 2000/01, Accra, pp. 33-75.

Rashid, M., M. Lone, and S. Ahmed. (2011). Integrating geospatial and ground geophysical information as guidelines for groundwater potential zones in hard rock terrains of south India. Environmental Monitoring and Assessment, 184, 4829-4839.

Saraf, A. K., \& Chowdhury, E. (1998). Integrated remote sensing and GIS for groundwater exploration and identification of artificial recharge sites. International Journal of Remote Sensing, 19(10), 1825-1841.
Sidhu, R.S., and Mehta, R.S. (1989). Delineation of groundwater potential zones in Kushawati river watershed a tributary of Zauri river in Goa, using remotely sensed data. In Proceedings of National Symposium on Engineering Applications of Remote Sensing and Recent Advantages, Indore (M.P), India, pp. 41-46.

Smith, A. Y., \& Blackwell, R. J. (1980). Development of an information data base for watershed monitoring. Photogrammetric Engineering \& Remote Sensing, 46, 1027-1038.

Subba Rao, N. (2006). Groundwater potential index in a crystalline terrain using remote sensing data. Environ. Geology, 50, 1067-1076.

Subba Rao, N. (2009). A numerical scheme for groundwater development in a watershed basin of basement terrain: a case study from India. Hydrology Journal, 17, 379-396.

Thenkabail, P. S., Smith, R. B., \& De Pauw, E. (2000). Hyperspectral vegetation indices and their relationships with agricultural crop characteristics. Remote Sensing of Environment, 71(2), 158-182.

Thenkabail, P. S., Enclona, E. A., Ashton, M. S., Legg, C., \& De Dieu, M. J. (2004). Hyperion, IKONOS, ALI, and ETM+ sensors in the study of African rainforests. Remote Sensing of Environment, 90(1), 23-43.

Titus, R., H. Beekman, S. Adams, and L. Strachan. (2009). The basement aquifers of Southern Africa. Water Research Commission report no. TT 428-09.

Trotter, C. M. (1991). Remotely sensed data as information source for geographical information system in natural resources management: a review. International Journal of Remote Sensing, 5, 225-239.

WHYMAP. (2008). Groundwater resources of the world. BGR/ UNESCO. Accessed at: http://www.whymap.org.

Woodford, A., P. Rosewarne, and J. Girman. (2006). How much groundwater does South Africa have? Accessed at: www.srk.co.uk/groundwater/PDFs/1_A_Woodford.pdf. 